\title{
RESPUBLIKINĖS VILNIAUS PSICHIATRIJOS LIGONINĖS PACIENTŲ SAVIŽUDYBĖS KRIZE் COVID-19 PANDEMIJOS AKIVAIZDOJE
}

\author{
Ieva Salialionė, Ieva Vaskelienė \\ Respublikiné Vilniaus psichiatrijos ligoniné
}

Raktažodžiai: savižudybės krizè, psichiatrijos pacientai, COVID-19 pandemija.

\begin{abstract}
Santrauka
Tyrimu siekta išsiaiškinti, kokio amžiaus, lyties ir kokius psichikos sutrikimus turintys Všl Respublikinès Vilniaus psichiatrijos ligoninès (RVPL) pacientai dažniau išgyvena savižudybės krizes, ar pandemija padažnino savižudybės krizes ir kokios grupès buvo labiausiai paveiktos. Tyrimo imtis - visi RVPL pacientai, kuriems nuo 2019 m. I ketvirčio iki 2021 m. II ketvirčio buvo atliktas savižudybės krizę išgyvenančių asmenų psichosocialinis vertinimas $(\mathrm{N}=1323$; amžius: nuo 10 iki 91 m., vid. 37,61 m.; 51,8 \% vyrų ir 48,2 \% moterų). Nustatyta, kad moterų imtyje savižudybès krizè dažniausiai pasitaiko 10-19 m. amžiaus, vèliau dažnis pastoviai mažèja; vyrų imtyje savižudybių krizių dažnis didèja nuo 10-19 m., pasiekia piką 30-39 m. amžiaus, o vèliau mažèja. Rečiausiai savižudybès krizes išgyvena $80>\mathrm{m}$. vyrai. Moterų imtyje savižudybès krizè dažniausia tarp pacienčių, kurių pagrindinè diagnozė yra šizofrenijos spektro sutrikimas; vyrų imtyje - asmenybès sutrikimas. Daugiau nei pusei savižudybès krizę išgyvenančių pacientų diagnozuotas sutrikimas dèl psichoaktyviųjų medžiagų (PAM) vartojimo. Dažniausia sutrikimų kombinacija - sutrikimas dèl PAM vartojimo kartu su asmenybès sutrikimu, ypač 20-49 m. amžiaus vyrų grupejje. Potrauminio streso sutrikimo diagnozė nustatoma ypač retai $(0,5 \%$ atvejų). Tiriamuoju laikotarpiu (nuo 2019 m. I ketvirčio iki $2021 \mathrm{~m}$. II ketvirčio) bendrasis savižudybių krizių dažnis nepakito, tačiau nustatyti pokyčiai atskirose grupèse: daugejja savižudybių krizių 30-39 m. ir 80> m. vyrų grupėse, tarp vyrų, kuriems nustatyti sutrikimai dèl PAM vartojimo ir organiniai psichikos sutrikimai; ir 70-79 m. moterų grupeje.
\end{abstract}

\section{Ivadas}

Savižudybės yra opi Lietuvos visuomenès problema. Nors pastaruoju dešimtmečiu savižudybių mažeja, ypač vyrų grupeje, Lietuvos rodikliai išlieka aukščiausi Europoje [1]. 2020 m. prasidèjusi COVID-19 pandemija išryškino naujus psichosocialinius veiksnius, kurie siejami su mintimis apie savižudybę: tai karantino sukelti adaptacijos sunkumai, vienatvè, dažnesnis buvimas namuose [2].

RVPL, teikiančioje specializuotas psichiatrijos paslaugas, vidutiniškai per metus gydoma apie 6000 pacientų. Iš jų maždaug dešimtadaliui reikalinga pagalba dèl patiriamos savižudybès grèsmès - pacientai ịvardija, kad galvoja apie savižudybę, ketina nusižudyti arba atvežami gydyti po méginimo žudytis. Remiantis Lietuvos Respublikos sveikatos apsaugos ministro $2018 \mathrm{~m}$. liepos $26 \mathrm{~d}$. įsakymu Nr. V-856 „Dèl savižudybès krizę išgyvenančių asmenų psichosocialinio vertinimo tvarkos aprašo", nuo $2018 \mathrm{~m}$. asmenims, kurie patiria savižudybès grèsmę, taikoma medicinos psichologo, vaikų ir paaugliu psichiatro arba psichiatro intervencija atliekamas savižudybès krizès įvertinimas ir sudaromas savisaugos planas.

Tyrimo tikslas - išsiaiškinti, kokių amžiaus grupių, kokios lyties ir kokių psichikos sutrikimų turintys pacientai dažniau išgyvena savižudybès krizes, taip pat ar pandemija dèl grèsmès savo bei artimujų sveikatai ir gyvybei bei dèl ekstremalios situacijos metu nepadažnino savižudybès krizių RVPL pacientų imtyje bei kokios grupès buvo labiausiai paveiktos.

\section{Tyrimo medžiaga ir metodai}

Tyrimo dalyviai. I tyrimo imtị itraukti visi RVPL pacientai, kuriems nuo $2019 \mathrm{~m}$. sausio $1 \mathrm{~d}$. iki birželio $30 \mathrm{~d}$. buvo atliktas savižudybės krizę išgyvenančių asmenų psichosocialinis vertinimas $(\mathrm{N}=1323)$. Amžius $-10-91 \mathrm{~m}$. (vid. $37,61 \mathrm{~m} ., \mathrm{SD}=16,57)$. Pasiskirstymas pagal lytị: 685 vyrai $(51,8 \%)$ ir 638 moterys (48,2 \%). Laikotarpiai: 10 ketvirčių 
nuo 2019 m. I ketvirčio iki 2021 m. II ketvirčio. Diagnozès nustatytos remiantis Tarptautinès ligų klasifikacijos 10 leidimo Australijos modifikacija (TLK-10-AM).

Duomenų analizè. Savižudybių krizių atvejų dažnių skirtumai tarp grupių nustatyti taikant Chi kvadrato kriterijų. Savižudybių krizių atvejų koreliacija su 10 ketvirčių laikotarpiu nustatyta taikant Pearson r koreliaciją.

\section{Rezultatai ir jų aptarimas}

Savižudybių krizių atvejai pagal lytị ir amžių. Lyginant savižudybių krizes patiriančius pacientus pagal lytị, panašiai tiek pat vyrų ir moterų išgyvena savižudybès krizes: 685 vyrai $(51,8 \%)$ ir 638 moterys $(48,2 \%)$.

Lyginant savižudybių krizių dažnị pagal amžių visoje tyrimo imtyje, savižudybių krizių dažnis didèja nuo 10 iki 29 m. amžiaus (10-19 m. grupèje dažnis yra 15,1\%), pasiekia piką 30-39 m. amžiuje $(21,4 \%)$, o vèlesnèse amžiaus grupèse dažnis mažeja; senyvo amžiaus
1 lentelè. Savižudybių krizių dažniai pagal amžių ir lytị.

\begin{tabular}{|c|c|c|c|c|c|c|}
\hline & \multicolumn{2}{|c|}{ Moterys } & \multicolumn{2}{|c|}{ Vyrai } & \multicolumn{2}{|c|}{ Iš viso } \\
\hline Amžius & $\mathrm{n}$ & proc. & $\mathrm{n}$ & proc. & $\mathrm{n}$ & proc. \\
\hline $10-19 \mathrm{~m}$. & 58 & $8,5 \%$ & 142 & $22,3 \%$ & 200 & $15,1 \%$ \\
\hline $20-29 \mathrm{~m}$. & 153 & $22,3 \%$ & 123 & $19,3 \%$ & 276 & $20,9 \%$ \\
\hline $30-39 \mathrm{~m}$. & 166 & $24,2 \%$ & 117 & $18,3 \%$ & 283 & $21,4 \%$ \\
\hline 40-49 m. & 155 & $22,6 \%$ & 105 & $16,5 \%$ & 260 & $19,7 \%$ \\
\hline $50-59 \mathrm{~m}$ & 83 & $12,1 \%$ & 77 & $12,1 \%$ & 160 & $12,1 \%$ \\
\hline $60-69 \mathrm{~m}$. & 42 & $6,1 \%$ & 42 & $6,6 \%$ & 84 & $6,3 \%$ \\
\hline $70-79 \mathrm{~m}$. & 15 & $2,2 \%$ & 19 & $3,0 \%$ & 34 & $2,6 \%$ \\
\hline $80+\mathrm{m}$. & 13 & $1,9 \%$ & 13 & $2,0 \%$ & 26 & $2,0 \%$ \\
\hline Iš viso & 685 & $100,0 \%$ & 638 & $100,0 \%$ & 1323 & $100,0 \%$ \\
\hline
\end{tabular}

(80> m.) pacientų, išgyvenančių savižudybès krizę, pasitaiko retai (2,0\%). Moterų ir vyrų savižudybès krizès dažnio dinamika pagal amžių nevienoda $\left(\chi^{2}=55,74 ; \mathrm{df}=7\right)$ : daugiausia mergaičių (moteru), išgyvenančių savižudybės krizę, yra 10-19 m. amžiaus grupejje (22,3\%), vèliau savižudybès krizių dažnis moterų grupèje pastoviai mažejja, rečiausiai savižudybès krizes išgyvena 80> m. moterys (2,0\%); vyrų imtyje savižudybių krizių dažnis didejja nuo 10-19 m. (8,5\%), pasiekia piką 30-39 m. amžiuje (24,2\%), o vèlesniame amžiuje dažnis mažèja, rečiausiai savižudybès krizes išgyvena $80>\mathrm{m}$. vyrai $(1,9 \%)$ (1 lentelè ir 1 pav.).

Savižudybių krizių atvejai pagal psichikos sutrikimo diagnozę. Lyginant

2 lentelẻ. Savižudybių krizių dažniai pagal pagrindinę diagnozę ir lytị.

\begin{tabular}{|c|c|c|c|c|c|c|c|c|}
\hline \multirow{3}{*}{ Diagnozé* } & \multicolumn{6}{|c|}{ Pagal pagrindinę diagnozę } & \multirow{2}{*}{\multicolumn{2}{|c|}{$\begin{array}{c}\text { Pagal visas diagnozes } \\
\text { Iš viso } \\
\end{array}$}} \\
\hline & \multicolumn{2}{|c|}{ Moterys } & \multicolumn{2}{|c|}{ Vyrai } & \multicolumn{2}{|c|}{ Iš viso } & & \\
\hline & $\mathrm{n}$ & proc. & $\mathrm{n}$ & proc. & $\mathrm{n}$ & proc. & $\mathrm{n}$ & proc. $* *$ \\
\hline F0 & 88 & $12,8 \%$ & 32 & $5,0 \%$ & 120 & $9,1 \%$ & 130 & $9,8 \%$ \\
\hline $\mathrm{F} 1$ & 125 & $18,2 \%$ & 107 & $16,8 \%$ & 232 & $17,5 \%$ & 744 & $56,2 \%$ \\
\hline $\mathrm{F} 2$ & 98 & $14,3 \%$ & 151 & $23,7 \%$ & 249 & $18,8 \%$ & 252 & $19,0 \%$ \\
\hline F3 & 54 & $7,9 \%$ & 109 & $17,1 \%$ & 163 & $12,3 \%$ & 180 & $13,6 \%$ \\
\hline F4 & 91 & $13,3 \%$ & 122 & $19,1 \%$ & 213 & $16,1 \%$ & 222 & $16,8 \%$ \\
\hline F5 & 0 & $0,0 \%$ & 6 & $0,9 \%$ & 6 & $0,5 \%$ & 15 & $1,1 \%$ \\
\hline F6 & 190 & $27,7 \%$ & 67 & $10,5 \%$ & 257 & $19,4 \%$ & 321 & $24,3 \%$ \\
\hline F7 & 19 & $2,8 \%$ & 11 & $1,7 \%$ & 30 & $2,3 \%$ & 79 & $6,0 \%$ \\
\hline F8 & 1 & $0,1 \%$ & 0 & $0,0 \%$ & 1 & $0,1 \%$ & 5 & $0,4 \%$ \\
\hline F9 & 19 & $2,8 \%$ & 33 & $5,2 \%$ & 52 & $3,9 \%$ & 55 & $4,2 \%$ \\
\hline Iš viso & 685 & $100,0 \%$ & 638 & $100,0 \%$ & 1323 & $100,0 \%$ & & \\
\hline $\begin{array}{l}\text { * F0 - organi } \\
\text { - šizofrenija, } \\
\text { somatoformin } \\
\text { F6 - suaugus } \\
\text { F9 - elgesio }\end{array}$ & $\begin{array}{l}\text { simpto } \\
\text { inis ir } 1 \\
\text { trikimai } \\
\text { smenyt } \\
\text { ijų sut }\end{array}$ & $\begin{array}{l}\text { miniai psicl } \\
\text { cliedesinis } \\
\text {; F5 - elges } \\
\text { ès ir elges } \\
\text { rikimai, pra }\end{array}$ & $\begin{array}{l}\text { sutrikin } \\
\text { imai; F3 } \\
\text { dromai } \\
\text { ikimai; } \\
\text { intys v }\end{array}$ & $\begin{array}{l}\text { i; F1 - psic } \\
\text { - nuotaiko } \\
\text { susiję su fi } \\
7 \text { - protini } \\
\text { ikystèje ir p }\end{array}$ & $\begin{array}{l}\text { s ir elges } \\
\text { ikimai; } \mathrm{F} \\
\text { giniais su } \\
\text { likimas; } \\
\text { lysteje. }\end{array}$ & $\begin{array}{l}\text { o sutrikima } \\
\text { - neurozir } \\
\text { rikimais ir } \\
8-\text { psicho }\end{array}$ & $\begin{array}{l}\text { idèl PAM var } \\
\text { iai, stresiniai } \\
\text { omatiniais ve } \\
\text { oginès raidos }\end{array}$ & $\begin{array}{l}\text { ojimo; F2 } \\
\text { ksniais; } \\
\text { sutrikimai; }\end{array}$ \\
\hline
\end{tabular}


savižudybių krizių dažni pagal pagrindinę diagnozę, dažniausiai savižudybès krizę patiria pacientai, kurių pagrindinè diagnozè yra asmenybès sutrikimas (19,4\%), šizofrenijos spektro sutrikimas $(18,8 \%)$, sutrikimas dèl psichoaktyviujų medžiagų (PAM) vartojimo $(17,5 \%)$ ir neurozinio spektro sutrikimai $(16,1 \%)$. Moterų ir vyrų savižudybès krizių dažniai pagal pagrindinę diagnozę skiriasi $\left(\chi^{2}=132,15 ; \mathrm{df}=9\right)$ : moterų imtyje savižudybės krizè dažniausia tarp pacienčių, kurių pagrindinė diagnozė yra šizofrenijos spektro sutrikimas $(23,7 \%)$, toliau pagal dažnį - neurozinio spektro sutrikimas $(19,1 \%)$, nuotaikos sutrikimas $(17,1 \%)$, sutrikimas dèl PAM vartojimo $(16,8 \%)$; vyrų imtyje savižudybès krizè dažniausia tarp pacientų, kuriems nustatytas asmenybès sutrikimas $(27,7 \%)$, toliau pagal dažni - sutrikimas dèl PAM vartojimo $(18,2 \%)$ (2 lentelè).

Papildomai atsižvelgiant ị amžių, nustatyta, kad moterų imtyje paauglystès amžiuje (10-19 m.) savižudybès krizè dažniausia tarp šizofrenijos spektro sutrikimą (30,3\%), nuotaikų sutrikimą $(23,2 \%)$ ir emocijų ir elgesio sutrikimą vaikystėje $(23,2 \%)$ turèjusių merginų; jauname suaugusiojo amžiuje (20-49 m.) savižudybės krizès dažniausios tarp neurozinio spektro, šizofrenijos spektro ir sutrikimą dèl PAM vartojimo turinčių pacienčių; brandžiame amžiuje (50-69 m.) - tarp sutrikimą dèl PAM vartojimo, šizofrenijos spektro ir nuotaikos sutrikimų turinčių pacienčių; senyvame amžiuje $(70>\mathrm{m}$.) - tarp organini psichikos sutrikimą turinčių pacienčių. Vyrų imtyje paauglystés amžiuje (10-19 m.) savižudybės krizè dažniausia tarp emocijų ir elgesio sutrikimą $(32,8 \%)$ ir šizofrenijos spektro sutrikimą $(20,7 \%)$ turinčių vaikinų; jaunystėje (20-29 m.) - tarp asmenybès sutrikimą turinčių jaunuoliu (36,6\%); jauname brandžiame amžiuje (30-49 m.) - tarp asmenybès sutrikimą ir sutrikimą dèl PAM vartojimo turinčių vyrų; $50-59 \mathrm{~m}$. amžiaus grupèje - tarp sutrikimą dèl PAM ir organini psichikos sutrikimą turinčių vyrų; $60>\mathrm{m}$. grupejje - tarp organini psichikos sutrikimą turinčių vyrų (1 pav.).

Aukščiau aprašyti savižudybių krizių dažniai pagal pagrindinę psichikos sutrikimo diagnozę. Pusei pacientų $(52,6 \%)$ buvo nustatyta vienai psichikos sutrikimo grupei priskiriamos diagnozės (pvz., jei pacientui nustatyta ir priklausomybè alkoholiui, ir abstinencija, tai laikyta viena psichikos sutrikimo grupe); didelei daliai pacientų $(43,4 \%)$ nustatytos dviejų psichikos sutrikimo grupių diagnozės (pvz., sutrikimas dèl PAM vartojimo ir asmenybès sutrikimas), o 4 proc. pacientų - net trijų psichikos sutrikimo grupių diagnozès (pvz., asmenybès sutrikimas, nuotaikos sutrikimas ir sutrikimas dèl PAM vartojimo). Analizuoti savižudybių krizių dažniai, atsižvelgiant ị visas asmeniui nustatytas psichikos sutrikimų diagnozes (nepriklausomai nuo to, kuris sutrikimas laikytas pagrindiniu šios hospitalizacijos metu). Nustatyta, kad daugiau nei pusė savižudybės krizę išgyvenančių pacientų turi sutrikimą dẻl PAM vartojimo (56,2\%); kiti sutrikimai savižudybès krizès atveju nustatomi gerokai rečiau: 24,3 proc. - asmenybès sutrikimas, 19,0 proc. - šizofrenijos spektro sutrikimas, 16,8 proc. - neurozinio spektro sutrikimas (2 lentelè). Dažniausia sutrikimų kombinacija savižudybès krizès atveju - sutrikimas dèl PAM vartojimo kartu su asmenybès sutrikimu $(\mathrm{n}=247 ; 18,7 \%$ visų savižudybès krizès

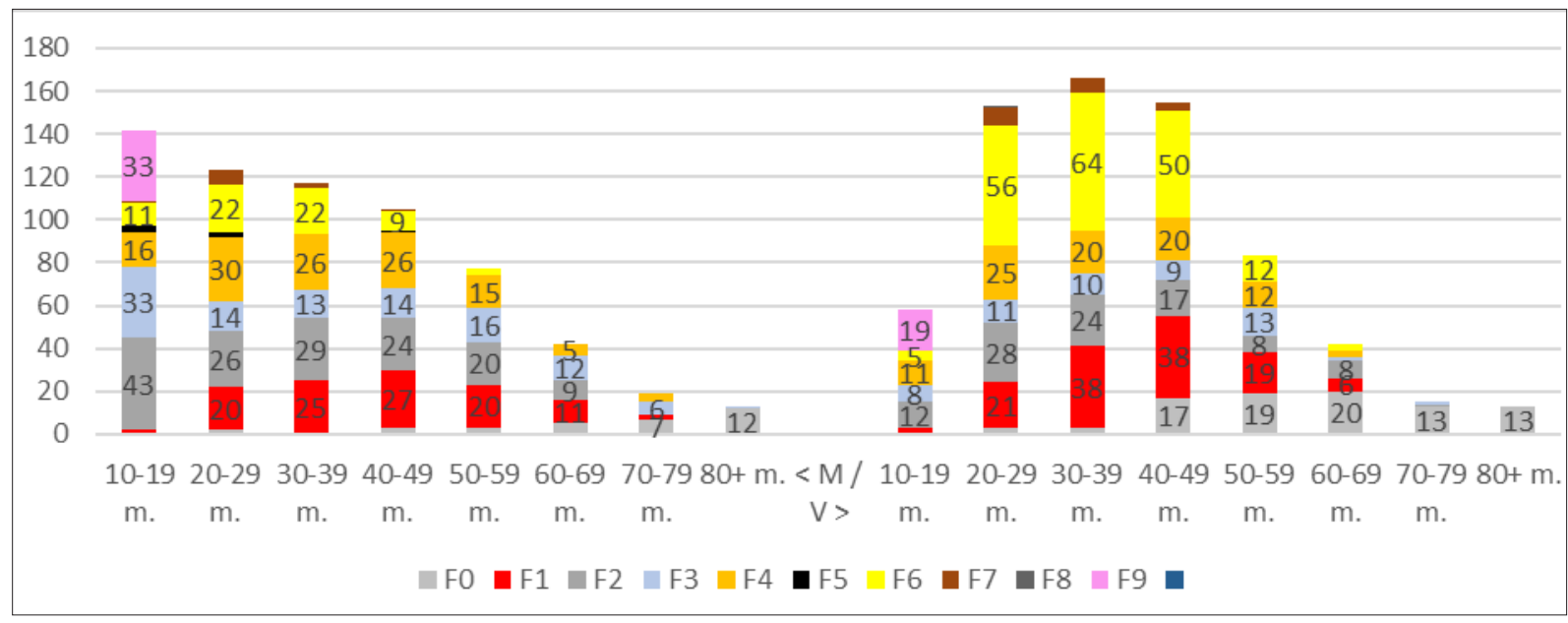

1 pav. Savižudybès krizės atvejų skaičius pagal lytị, amžių ir pagrindinę diagnozę (n)

Kaireje pateikiami moteru duomenys (,,M“), dešinejje - vyru duomenys (,, V“). F0 - organiniai ir simptominiai psichikos sutrikimai; F1 - psichikos ir elgesio sutrikimai dèl PAM vartojimo; F2 - šizofrenija, šizotipinis ir kliedesinis sutrikimai; F3 - nuotaikos sutrikimai; F4 - neuroziniai, stresiniai ir somatoforminiai sutrikimai; F5 - elgesio sindromai, susiję su fiziologiniais sutrikimais ir somatiniais veiksniais; F6 - suaugusiuju asmenybès ir elgesio sutrikimai; F7 - protinis atsilikimas; F8 - psichologinès raidos sutrikimai; F9 - elgesio ir emociju sutrikimai, prasidedantys vaikystëje ir paauglystèje. 


\section{4}

atvejų); ši sutrikimų kombinacija dažniausia 20-49 m. vyrų grupèje ( $\mathrm{n}=171 ; 12,9 \%$ visų savižudybès krizès atvejų).

Svarbu paminèti, kas neatsispindi šioje psichikos sutrikimų statistikoje. Klinikinejje praktikoje galima pastebèti, kad savižudybės krizę išgyvenantys pacientai yra patyrę ìvairių potencialiai traumuojančių ịvykių, kurie jiems yra emociškai reikšmingi. Vis dèlto žvelgiant ị šią statistiką, galima daryti prielaidą, kad su potrauminemis reakcijomis susiję sutrikimai yra mažai pastebimi - diagnozių sąlyginai nedaug. Iš visų 1323 pacientų F43 grupès „Reakcijos ị didelị stresą ir adaptacijos sutrikimai“" nustatyti 14,2 proc. (n = $188)$ pacientų: 13,5 proc. $(\mathrm{n}=178)$ pacientų diagnozuotas adaptacijos sutrikimas (F43.2), 0,5 proc. $(\mathrm{n}=6)$ - potrauminio streso sutrikimas (F43.1), 0,2 proc. $(\mathrm{n}=3)$ - ūminè reakcija ị stresą (F43.0) ir 0,1 proc. $(\mathrm{n}=1)$ - kitos reakcijos i stiprų stresą (F43.8). Tai atitinka 2014-2015 m. Lietuvos rodikliu analizès rezultatus, kuriais remiantis daroma išvada, kad Lietuvos sveikatos sistema identifikuoja tik apie 1 proc. potencialių potrauminio streso sutrikimo atvejų per metus [3]. Tai reiškia, kad dauguma žmonių, patiriančių potraumini stresą, lieka nepastebėti ir negavę tinkamos profesionalios specializuotos pagalbos. Gali būti, kad kai kuriais atvejais alkoholis ar kitos psichotropinès medžiagos tampa savigydos priemonėmis. Remiantis užsienio tyrimų sistemine analize, potrauminis streso sutrikimas ir piktnaudžiavimas alkoholiu yra komorbidiški: potrauminio streso paplitimas tarp asmenu, kuriems nustatytas piktnaudžiavimas alkoholiu, varijuoja nuo 2 iki 60 procentų [4].

Savižudybių krizių dažnis iki Covid-19 pandemijos ir jos metu. Siekta nustatyti, ar savižudybių krizių dažnis kito pastarujų 2,5 metų laikotarpiu, pradedant ikipandeminiais metais ir baigiant pandeminių metu antrojo karantino pabaiga. Tam tikslui ieškota ryšio tarp savižudybių krizių dažnio bei 10 ketvirčių (nuo 2019 m. I ketvirčio iki 2021 m. II ketvirčio). Visoje imtyje savižudybių krizių dažnis nepakito $(r=0,450 ; p=0,192)$ - pandemija ir gyvenimo suvaržymai neturèjo reikšmingos įtakos RVPL pacientų savižudybių krizių dažniui. Nustatyti savižudybès krizių dažnių pokyčiai atskirose grupèse. Pagal lytị, pastarujų 2,5 metų laikotarpiu daugejo vyrų savižudybių krizių $(r=0,703 ; p=0,023)$, o moterų savižudybių krizių dažnis nekito $(r=0,000 ; p=1,000)$. Vyrų amžiaus grupèse pastarųjų 2,5 metų laikotarpiu mažèjo $10-19 \mathrm{~m}$. vaikinų savižudybių krizių $(r=-0,680 ; p=0,031)$, daugèjo $30-39 \mathrm{~m} .(r=0,876 ; p=0,001)$ ir $80>\mathrm{m}$. vyru savižudybių krizių ( $r=0,660 ; p=0,038)$; kitose amžiaus grupèse reikšmingų ryšių nenustatyta. Moterų amžiaus grupèse pastarujų 2,5 metų laikotarpiu daugejo $70-79 \mathrm{~m}$. moteru savižudybių krizių $(r=0,768 ; p=0,009)$, kitose amžiaus grupèse reikšmingų ryšių nenustatyta. Vertinant visus pacien- tams diagnozuotus psichikos sutrikimus atsižvelgiant ị lytị, pastarujų 2,5 metų laikotarpiu savižudybių krizių daugèjo tarp vyrų, kuriems nustatyti organiniai psichikos sutrikimai $(r=0,835 ; p=0,003)$ ir sutrikimai del PAM vartojimo $(r=$ $0,635 ; p=0,049)$, savižudybių krizių mažèjo vaikinams ir merginoms, kuriems emocijų ir elgesio sutrikimai nustatyti vaikysteje (atitinkamai $r=-0,916 ; p=0,000$ ir $r=-0,668 ; p$ $=0,035$ ). Savižudybių krizių dažnio vaikų ir paauglių grupejje mažèjimas sietinas su pokyčiais RVPL - mažinamas paslaugų teikimas vaikams ir paaugliams, nepilnamečius nukreipiant pagalbos ị kitas gydymo įstaigas.

Nors pandemijos laikotarpiu savižudybių krizių RVPL pacientams nepadaugèjo, tačiau stebimi pokyčiai atskirose grupèse: daugèjo vyrų savižudybių 30-39 m. ir 80> m. grupèse ir tarp tų, kuriems nustatyti sutrikimai dèl PAM vartojimo ir organiniai psichikos sutrikimai; dažnejo 70-79 m. moteru savižudybių krizių. Galima daryti prielaidą, kad pandemijos ribojimai labiausiai paveikè jaunus, darbingo amžiaus vyrus, kurie pandemijos metu galimai dèl darbo ribojimų pradejo daugiau vartoti PAM bei išgyventi gyvenimo beprasmybės jausmą, bei senyvo amžiaus žmones, turinčius organinių psichikos sutrikimų, kurie galimai dèl priverstinai apriboto bendravimo su artimaisiais, pagalbos prieinamumo sumažějimo jautėsi vieniši, apleisti ir nebereikalingi.

\section{Išvados}

1. Moterų imtyje savižudybės krizė dažniausia 10-19 m. amžiuje, vèlesniame amžiuje dažnis pastoviai mažeja; vyrų imtyje savižudybių krizių dažnis didèja nuo 10-19 m., pasiekia piką 30-39 m., o vèlesniame amžiuje mažèja, rečiausiai savižudybès krizes išgyvena $80>\mathrm{m}$. vyrai.

2. Moterų imtyje savižudybès krizė dažniausia pacientėms, kurių pagrindinè diagnozè yra šizofrenijos spektro sutrikimas; vyrų - asmenybės sutrikimas.

3. Daugiau nei pusei savižudybès krizę išgyvenančių pacientų yra diagnozuotas sutrikimas dèl PAM vartojimo. Dažniausia sutrikimų kombinacija savižudybės krizės atveju - sutrikimas dél PAM vartojimo kartu su asmenybès sutrikimu, ypač 20-49 m. amžiaus vyrų grupèje.

4. Potrauminio streso sutrikimo diagnozè nustatoma ypač retai $(0,5 \%$ atvejų); tai atskleidžia psichikos sveikatos sistemos spragą nustatant šiuos sutrikimus bei teikiant specializuotą pagalbą.

5. Nuo 2019 m. I ketvirčio iki $2021 \mathrm{~m}$. II ketvirčio bendras savižudybių krizių dažnis nepakito, tačiau nustatyta pokyčių atskirose grupėse: daugèjo savižudybių krizių 30-39 m. ir 80> m. vyrų grupėse; tarp vyrų, kuriems nustatyti sutrikimai dèl PAM vartojimo bei organiniai psichikos sutrikimai ir 70-79 m. moteru grupejje. 


\section{Literatūra}

1. Valstybinis psichikos sveikatos centras. Savižudybių statistika, 2020. https://vpsc.lrv.lt/lt/statistika/savizudybiu-statistika

2. Gelezelyte O, Dragan M, Grajewski P, Kvedaraite M, Lotzin A, Skrodzka M, Nomeikaite A, Kazlauskas E. Factors associated with suicide ideation in Lithuania and Poland amid the COVID-19 Pandemic. Crisis 2021. https://doi.org/10.1027/0227-5910/a000814

3. Kazlauskas E, Zelviene P, Eimontas J. No postraumatic stress disorder in Lithuania. National health care fails to identify PTSD. Journal of Traumatic Stress 2017;30(1):99-102. https://doi.org/10.1002/jts.22152

4. Debell F, Fear NT, Head M, Batt-Rawden S, Greenberg N, Wessely S, Goodwin L. A systematic review of comorbidity between PSTD and alcohol misuse. Social Psychiatry and Psychiatric Epidemiology 2014; 49(9):1401-25.

https://doi.org/10.1007/s00127-014-0855-7

\section{SUICIDE CRISIS AMONG PATIENTS OF REPUBLICAN VILNIUS PSYCHIATRIC HOSPITAL IN THE FACE OF COVID-19 PANDEMIC \\ I. Salialionè, I.Vaskelienè}

Keywords: suicide crisis, psychiatric patients, COVID-19 pandemic.

Summary

The aim of this study was to find out at what age, what gender and with what mental disorders patients of Republican Vilnius psychiatric hospital (RVPH) were more likely to experience suicide crisis, as well whether the pandemic increased suicide crisis rates and which groups were affected the most. This study sample - all RVPH patients who in the period of 2019 I quarter to 2021 II quarter were assessed with psychosocial assessment form for people surviving suicide crisis ( $\mathrm{N}=1323$; age: from 10 to 91 , mean 37,$61 ; 51,8 \%$ men and 48,2 \% women). In the sample of women, suicide crisis was found to be most common among 10-19 years of age, the frequency decreased steadily in the later age; in the sample of men, the frequency of suicide crisis increased from 10-19 years of age, reached a peak in 30-39 years of age, and later it decreased, suicide crisis was the rarest in $80+$ years men. In the sample of women, suicide crisis was most common among patients with a primary diagnosis of schizophrenia spectrum disorder, while in a sample of men - with a personality disorder. More than half of the patients experiencing a suicide crisis have been also diagnosed with a disorder related to the use of psychoactive substances (PAS). The most common combination of disorders was a disorder related to the use of PAS in combination with a personality disorder, especially in the 20-49 age group of men. The diagnosis of PTSD was extremely rare $(0.5 \%$ of cases). In general, in the period from 2019 I quarter to 2021 II quarter the frequency of suicide crisis did not change, yet changes were found in separate groups: the number of suicide crisis increased in 30-39 and 80+ groups of men, who were diagnosed with disorders related to PAS use and organic mental disorders; also, in a group of 70-79 years old women.

Correspondence to: ieva.vaskeliene@rvpl.1t

Gauta 2021-11-04 